INTERNATIONAL FOOD

POLICY RESEARCH INSTITUTE

sustainable solutions for ending hunger and poverty

Supported by the CGIAR

IFPRI Discussion Paper 00976

May 2010

\title{
The Medium-Term Impact of the Primary Education Stipend in Rural Bangladesh
}

\section{Bob Baulch}

Poverty, Health, and Nutrition Division 


\title{
INTERNATIONAL FOOD POLICY RESEARCH INSTITUTE
}

The International Food Policy Research Institute (IFPRI) was established in 1975. IFPRI is one of 15 agricultural research centers that receive principal funding from governments, private foundations, and international and regional organizations, most of which are members of the Consultative Group on International Agricultural Research (CGIAR).

\section{PARTNERS AND CONTRIBUTORS}

IFPRI gratefully acknowledges the generous unrestricted funding from Australia, Canada, China, Denmark, Finland, France, Germany, India, Ireland, Italy, Japan, the Netherlands, Norway, the Philippines, South Africa, Sweden, Switzerland, the United Kingdom, the United States, and the World Bank.

\section{AUTHOR}

Bob Baulch, Chronic Poverty Research Centre

Coordinator, Poverty Dynamics and Economic Mobility Theme

\begin{abstract}
Notices
${ }^{1}$ Effective January 2007, the Discussion Paper series within each division and the Director General's Office of IFPRI were merged into one IFPRI-wide Discussion Paper series. The new series begins with number 00689, reflecting the prior publication of 688 discussion papers within the dispersed series. The earlier series are available on IFPRI's website at http://www.ifpri.org/publications/results/taxonomy\%3A468.

2 IFPRI Discussion Papers contain preliminary material and research results. They have not been subject to formal external reviews managed by IFPRl's Publications Review Committee but have been reviewed by at least one internal and/or external reviewer. They are circulated in order to stimulate discussion and critical comment.
\end{abstract} material contained herein for profit or commercial use requires express written permission. To obtain permission, contact the Communications Division at ifpri-copyright@cgiar.org. 


\section{Contents}

Abstract $\quad$ V

Acknowledgements vi

1. Introduction 1

2. Overview of the PES Program in Bangladesh 2

3. Data 4

4. Methodology 8

5. Descriptive Analysis of the Impact of Education Transfers 10

6. Empirical Results 15

7. Conclusions and Policy Implications 20

Appendix: Supplementary Figure and Tables $\quad 21$

References $\quad 23$ 


\section{List of Tables}

1. Change in outcome variables, 2000-2006 6

2. Targeting of the Primary Education Stipend (PES) program, 2003 12

3. Targeting of the Primary Education Stipend (PES) program, $2006 \quad 12$

4. Change in outcome variables by Primary Education Stipend (PES) status 13

5. Household-level impacts of the Primary Education Stipend, 2000-2006 16

6. Household-level impacts of the Primary Education Stipend in restricted sample, 2000-2006 17

7. Individual-level impacts of the Primary Education Stipend, 2000-2006 18

8. Individual-level impacts of the Primary Education Stipend, 2000-2006 19

A.1. Probit estimates of the propensity score at the household level 22

A.2. Probit estimates of the propensity score at the individual level 22

\section{List of Figures}

1. The declining value of educational transfers 3

2. Primary Education Stipend (PES) recipients, by age 10

3. Proportion of households receiving educational transfers 11

4. Proportion of children enrolled in school, by Primary Education Stipend (PES) beneficiary status 14

5. Estimated propensity score at the household leve 15

6. Estimated propensity scores at the individual level 18

A.1. Locations of the education transfer survey sites 21 


\begin{abstract}
This paper investigates the long-term impact of Bangladesh's Primary Education Stipend (PES) program on a range of individual and household welfare measures using a unique longitudinal study spanning the years 2000 to 2006. Using covariate and propensity score matching and difference-in-difference methods, the program is shown to have negligible impacts on school enrollments, household expenditures, calorie consumption, and protein consumption. At the individual level, the PES has a negative impact on grade progression, especially among boys from poor households who are ineligible to receive stipends at the secondary level. The program does, however, lead to improvements in height for age among girls and body mass index among boys. Nonetheless, the impacts of the PES are remarkably small for a program of its size. Poor targeting combined, in particular the program's limited coverage and lack of geographical targeting, plus the declining real value of the stipend are the most plausible reasons for this lack of impact.
\end{abstract}

Keywords: Bangladesh, conditional cash transfers, primary education 


\section{ACKNOWLEDGEMENTS}

The author * thanks Akhter Ahmed, Peter Davis, Neha Kumar, Agnes Quisumbing, and an anonymous reviewer comments for helpful on earlier versions of this paper and Wahid Quabili for help with preparing and understanding the dataset.

This research was funded by the UK Economic and Social Research Council and Department for International Development under their Joint Research Scheme (Award Number RES 167-25-0361).

${ }^{*}$ Bob Baulch is also a Research Fellow with the Social Development Research Initiative (www.sdri.org.uk) and Lead Economist for the Prosperity Initiative (www.prosperityinitiative.org). 


\section{INTRODUCTION}

Education is known to be one of the key investments than can interrupt the intergenerational transmission of poverty (CPRC 2004). Since the late 1990s, there has been a wave of interest in educational transfer programs that provide cash and other incentives to poor parents who send their children to school (Parker, Rubalcava, and Teruel 2006; Fiszbein and Schady 2009). Bangladesh has some of the longest-running education transfer programs in the world, starting with the Food for Education (FFE) program in 1993, which predate the current wave of interest in educational transfer programs. This paper investigates the long-term impact of Bangladesh's Primary Education Stipend (PES) program on a range of individual and household welfare measures using a unique longitudinal study spanning the years from 2000 to 2006. It is one of a series of comparative papers being written under the DFID-ESRC funded project "What Development Interventions Work? The Long-term Impact of Anti-poverty Interventions in Bangladesh," led by the International Food Policy Research Institute.

The next section sets the context with an overview of Bangladesh's education transfer programs, after which the data and the evaluation methods used are described in Sections 3 and 4. Section 5 provides some descriptive (bivariate) analysis of the impacts of the PES program, while Section 6 contains estimates of the impact of the programs on household- and individual-level outcomes using propensity matching. Section 7 concludes. 


\section{OVERVIEW OF THE PES PROGRAM IN BANGLADESH}

The PES program aims to increase school enrollments and attainments by providing cash incentives for poor parents to send their children to school. Since mid-2002, households with qualifying pupils who attend school 85 percent of the time have received BDT100 per month for one child (about US $\$ 1.76^{1}$ ) and BDT125 per month for more than one child. To qualify for the program, children must be of primaryschool age and meet at least one of the following five eligibility criteria:

1. belonging to a landless or near-landless household (one that owns less than half an acre of land);

2. having parents who work as day laborers;

3. belonging to a female-headed household (one wherein the head is widowed, separated, or divorced or wherein the husband is disabled);

4. belonging to a household that derives its living from fishing, pottery, weaving, blacksmithing, or cobbling); or

5. belonging to a household that derives its income from sharecropping.

The PES program replaced the FFE program in mid-2002. In 2002, the FFE program provided beneficiary households with a free ration of 15 kilograms of wheat or 12 kilograms of rice per month for sending one child of the appropriate age to primary school. ${ }^{2}$ The eligibility criteria for FFE were similar to those of PES except that children of sharecropping households were not entitled to receive food rations. However, unlike the PES program, which covers all rural areas, the FFE program was implemented selectively in economically disadvantaged rural union councils (administrative groups of villages) only. At its peak in 2002, FFE was implemented in 1,255 unions covering 27 percent of the country (Tietjen 2003). The main reasons for the replacement of the FFE program were concerns about its cost, poor targeting, and geographic selectiveness, together with criticisms, probably inflated, about the high level of leakages from the program (Ahmed 2005). This led to a government decision in December 2001 to abandon the FFE program and a budget allocation for the stipend of BDT6.63 billion (approximately $\$ 120$ million) in the June 2002 budget. A detailed account of the historical development of both the FFE and the PES programs is provided in the companion paper by Ahmed and Khondakar (2009).

The PES program was rolled out in the period between July 2002 and January 2003.

During the first phase of its implementation, from then until to 2007, the Ministry of Primary and Mass Education estimated that 5.5 million children received the stipend at a budgetary cost of BDT2.82 billion (approximately $\$ 45$ million). Al-Samarrai (2007) states that in 2004/05 almost a fifth (19 percent) of the primary education budget was spent on the PES program.

The term of PES was extended by one year in 2007 and then renewed for a second phase in July 2008 for a further five years (until June 2013). The budgetary allocation for the second phase of the PES program between 2008 and 2013 is BDT2.44 billion (\$37 million), with 4.8 million children expected to benefit from the program (Ministry of Primary and Mass Education n.d.).

Under the PES program, six designated national banks disburse the stipends on a quarterly basis to authorized parents/guardians on predetermined dates at the local bank branches or at temporary distribution points ("camps") established within 5 kilometers of the school (Tietjen 2003). Stipends were disbursed to pupils' parents or legal guardians on presentation of bank-issued identity cards (preference was given to mothers in the issuance of these identity cards). Due to the dramatic expansion of nongovernment primary schools in the late 1990s, the range of schools whose pupils were eligible to receive education transfers was also extended to include approved full primary schools run by NGOs. However, BRAC (Bangladesh Rural Advancement Committee) community schools and other NGO

\footnotetext{
${ }^{1}$ All dollars are U.S. dollars.

${ }^{2}$ If households had more than one primary school-age child and sent them all to primary school, the monthly ration was increased to 20 kilograms of wheat or 16 kilograms of rice (Ahmed and del Ninno 2002).
} 
schools without the full range of grades (one to five) are excluded from the program. So too are all urban primary schools. This reflects the traditional political consensus that poverty is mostly a rural issue in Bangladesh, together with a desire not to encourage rural-urban migration (Al-Samarrai 2009). ${ }^{3}$

School management committees with the assistance of head teachers are responsible for selecting children who meet the five eligibility criteria, who are expected to be from the poorest 40 percent of households (Tietjen 2003). The list of children selected to receive PES is then reviewed and approved by the upazila education officer and executive officer (Ahmed 2005).

It is important to note that the nominal value of PES has been fixed at BDT100 for the first child and BDT125 for two or more children since its inception. Given inflation, this means that in real terms, the value of the monthly PES stipend has been declining since 2003. Put differently, BDT100 would buy 11 kilograms of atta (wheat flour) and 7.5 kilograms of rice in late 2003 and 6.1 or 6.2 kilograms of wheat or rice in late 2006 (Figure 1). ${ }^{4}$ A similar calculation suggests that at the height of the food crisis in August 2008, PES would buy around 3.3 kilograms of wheat and 3.1 kilograms of rice. When these volumes are compared to 15 kilograms of wheat or 12 kilograms of rice that were provided as the monthly ration by the FFE program, it is clear that the value of educational transfers has declined substantially since the introduction of PES.

\section{Figure 1. The declining value of educational transfers}

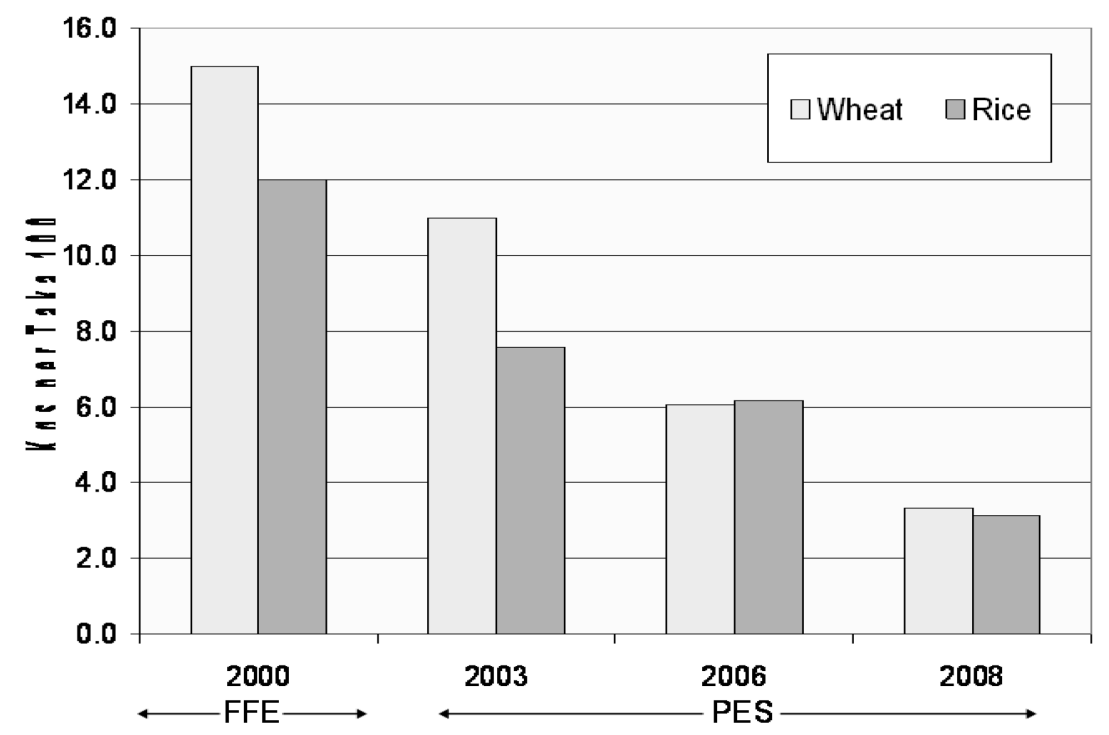

Source: Author's creation.

Note: Kgs = kilograms; FFE = Food for Education; PES = Primary Education Stipend.

The life history interviews that were conducted as part of the study (see next section) confirm that while the FFE and PES programs were seen as contributing positively to the life histories of 29 percent of individuals, the impact of the transfer was limited by the relatively low value of the benefits (Davis, forthcoming). Only a small number of respondents reported that children might have been withdrawn from school without the transfers.

\footnotetext{
${ }^{3}$ In addition, primary schools attached to higher-level madrasahs (Dakhil) are excluded from the PES program for administrative reasons (Al-Samarrai 2009).

${ }^{4}$ This calculation was made using the domestic wholesale market prices in Dhaka for November/December, quoted in the Food Policy Monitoring Unit's quarterly Bangladesh Food Situation Reports (FPMU, various dates).
} 


\section{DATA}

The data used in this paper come from a three-wave panel survey of 511 households in 8 upazilas (subdistricts) in rural Bangladesh, in which the same households were interviewed in 2000, 2003, and 2006. The panel builds on an International Food Policy Research Institute (IFPRI) evaluation of the impact of the FFE program conducted in 2000 (Ahmed and del Ninno 2002). In the first evaluation, 600 households in 60 villages in 30 union councils in 10 upazilas were surveyed, with two-thirds of the unions being unions in which the FFE program was active and the remaining third being non-FFE unions. ${ }^{5}$ As the focus of the FFE program was on economically disadvantaged areas, the sample of non-FFE unions was selected from neighboring economically disadvantaged areas. This means that the subsequent sample cannot be regarded as representative of rural Bangladesh as a whole, but it does broadly characterize the conditions in the poorest upazilas in the country.

With the advent of the PES program in July 2002, there was interest in comparing the impact of the PES with the FFE program, and IFPRI was commissioned to undertake a second evaluation study by the World Bank in 2003. Because of budgetary constraints, only 8 of the 10 original upazilas were surveyed, and it was also decided to follow only the original households within the survey unions. The combined effect of these changes reduced the household sample from 600 to 473 households in the second wave, although only 7 of these lost households should strictly be regarded as the result of attrition, as the other 120 households came from the two unions that were not surveyed in 2003. Although the same proportions of former FFE and non-FFE unions were maintained in 2003, as all rural unions were now eligible for the PES, the treatment-control design used by the previous evaluation could not be applied to evaluation of the PES program (Ahmed 2005).

In late 2006/early 2007, the same households and unions that had been included in the 2003 wave were resurveyed as part of a larger Chronic Poverty Research Centre -IFPRI project entitled "Chronic Poverty and Poverty Dynamics in Rural Bangladesh." Households from two other IFPRI evaluation studies on microfinance (1994) and agricultural technologies (1996) were also included in this study, increasing the surveys' total sample size to 2,152 households. In this wave, adult male children who had left the original households and set up their own households were tracked as long as they had not migrated outside their home districts. In addition, anthropometric information for all present household members, GPS coordinates of households and facilities, and several specialized modules (on shocks and negative events as well as power and resources) were included in the household questionnaire. The 2006/07 study aimed to integrate and sequence quantitative and qualitative methods in three phases:

- Phase I involved focus-group discussions with four groups (of poor and better-off women, plus poor and better-off men) in each village. The focus groups aimed to elicit perceptions of changes, group members' perceptions of the interventions under study, and the degree to which these interventions affected people's lives (compared to other events in the community).

- Phase II was a quantitative survey of the original households and new households that had split off from the original households but remained in the same district. The household survey took place from November 2006 to February 2007, the same agricultural season as the original surveys, with multitopic questionnaires designed to be comparable across sites and with the original questionnaires from the evaluation studies.

\footnotetext{
${ }^{5}$ The 10 upazilas were selected with probability proportionate to size samples (using population data from the most recent census), and then two Food for Education (FFE) unions and one non-FFE union were selected in each union. Two villages were then randomly selected in each union, with 10 households with primary school-age children then randomly selected within each village. See Ahmed and del Ninno (2002) for further details.
} 
- Phase III consisted of a qualitative study based on life histories of 293 men and women in 161 selected households in eight of the districts in the original quantitative study. ${ }^{6}$ The aim of this phase was to understand the processes and institutional contexts that influence individual and household livelihood trajectories. Fieldwork for this final phase of the study was undertaken between March and October 2007.

Further details about the sampling and initial findings from these three phases of the 2006/07 survey can be found in Davis (2007), Quisumbing (2007), and Davis and Baulch (2009), respectively. Appendix Figure 1. provides a map of the locations of the upazilas surveyed.

Only the part of the 2006/07 household survey that was drawn from the original FFE study in 2000 is analyzed in this paper. This consists of 511 households, consisting of 473 core households from the 2000 survey plus 38 households that had split from the core households between 2003 and 2006 . $^{7}$ Since there were 480 households in the 2000 survey that could have been resampled, and 31 of these were not relocated in 2006, the attrition rate is 6.1 percent. Although this is a relatively low rate of attrition compared to those of panel surveys in other developing countries, Quisumbing's (2007) multivariate analysis of attrition in the three sites indicates that attrition is not entirely random, with demographic variables and village dummies being predictors of attrition.

Two characteristics of the data that deserve highlighting are the percentage of villages with primary schools in the sample and panel ageing. First, of the 48 villages included in the education transfer panel, 41 had registered primary schools (all of which were coeducational), and 18 had two or more primary schools (including nine madrasahs with attached primary schools). All but 1 of these 41 villages had at least one primary school before 2000. Second, because the original 2000 sample was designed to include households with at least one primary-school-age child, the percentage of households with primary-school-age children declines (from 97.8 percent in 2000 to 97.7 percent in 2003 and 60.1 percent in 2006). This does not indicate a fall in the primary enrollment rate but rather the ageing of panel households. Net enrollment rates in primary school have, in fact, increased from 84.0 percent in 2000 to 92.2 percent in $2006 .{ }^{8}$ Furthermore, primary Net Enrolment Rates (NERs) for girls are around 2.0 percent higher than for boys in both 2000 (85.2 percent vs. 82.8 percent) and 2006 (93.3 percent vs. 91.0 percent). ${ }^{9}$

Table 1 shows changes in the outcome variables, which I have derived from the panel survey for the period 2000-2006. As my interest is the impact of PES, the sample is restricted to those households with at least one primary-school-age child in $2006 .{ }^{10}$ Two levels of outcome variables are distinguished in Table 1 and throughout the remainder of this paper: household-level and individual-level variables. The household-level variables are much more numerous than the individual-level variables as they include variables such as expenditures and assets that can be measured meaningfully only at the household level. When such variables were measured in monetary units, they were first converted into real 2006/07 terms and then transformed into natural logarithms. They therefore have a percentage change interpretation (for example, per capita expenditures increased by 41 percent in real terms between 2000 and 2006). Changes in calorie and protein consumption, which are expressed as kilocalories and calories per day, are also changes in logs. To account for differences in household composition, changes per adult equivalent expenditures, calorie, and protein consumption are also calculated using the equivalence scale developed by Ahmed and Sharma (1996). Again, these changes are in log terms, so a percentage interpretation is

\footnotetext{
${ }^{6}$ In six of these eight districts, focus group discussions were carried out in Phase I.

${ }^{7}$ Note that household splits were not followed between 2000 and 2003.

${ }^{8}$ For consistency with previous International Food Policy Research Institute reports we use 6 to 12 years old as the age range for calculating primary enrollment rates although the official age range for primary education is 6 to 10 years old. The World Bank's lower estimates of primary NERS are based on using the official age range.

${ }^{9}$ This suggests that Bangladesh has achieved gender parity in education, at least at the primary level. These trends are consistent with those that have been observed in nationally representative household surveys, such as the Household Income and Expenditure Surveys of 2000 and 2005 (World Bank 2008).

${ }^{10}$ Most of these households have several children of different ages.
} 
possible. Land assets, which cannot be valued in 2000, are measured as the percentage change in land owned per household in decimals. ${ }^{11}$ Finally, three household-level outcomes are included, which are summaries of individual-level outcomes: change in the percentage of stunting among children younger than 12, change in the percentage of children younger than 12 with low body mass indices (BMIs), and change in the percentage of school-aged children in the household enrolled in primary school. ${ }^{12}$ These are the outcomes that perhaps speak most directly to the objectives of PES and, along with protein consumption, are also the outcomes that show declines in their mean values, although none of these are statistically different from zero at conventional levels. The size of the decline in the percentage of children enrolled in primary school is nonetheless large and is linked to the phenomenon of panel ageing.

Table 1. Change in outcome variables, 2000-2006

\begin{tabular}{|c|c|c|c|c|c|}
\hline Outcome Variable & $n$ & Mean & $\begin{array}{l}\text { Standard } \\
\text { Deviation }\end{array}$ & Minimum & Maximum \\
\hline \multicolumn{6}{|c|}{$\underline{\text { Household-level Outcomes }}$} \\
\hline Change in per capita expenditures & 291 & 0.415 & 0.4621 & -1.18 & 1.72 \\
\hline Change in per capita food expenditures & 291 & 0.390 & 0.4646 & -1.38 & 1.68 \\
\hline Change in per capita nonfood expenditures & 289 & 0.637 & 0.7977 & -2.50 & 2.81 \\
\hline Change in adult equivalent expenditures & 291 & 0.914 & 0.5059 & -0.65 & 2.62 \\
\hline Change in adult equivalent food expenditures & 291 & 0.890 & 0.5213 & -0.82 & 2.56 \\
\hline Change in adult equivalent nonfood expenditures & 289 & 1.138 & 0.8042 & -1.86 & 3.51 \\
\hline Change in per capita calorie consumption & 290 & 0.034 & 0.3644 & -1.13 & 0.92 \\
\hline Change in per capita protein consumption & 290 & -0.289 & 0.4542 & -1.60 & 0.99 \\
\hline Change in adult equivalent calorie consumption & 290 & 0.534 & 0.4430 & -1.00 & 1.92 \\
\hline Change in adult equivalent protein consumption & 290 & 0.212 & 0.5132 & -1.36 & 1.62 \\
\hline $\begin{array}{l}\text { Change in percentage of stunting among children younger } \\
\text { than } 12\end{array}$ & 291 & 0.118 & 0.4386 & -1.00 & 1.00 \\
\hline $\begin{array}{l}\text { Change in percentage of low BMI among children younger } \\
\text { than } 12\end{array}$ & 291 & 0.076 & 0.3888 & -1.00 & 1.00 \\
\hline Change in percentage of children enrolled in primary school & 291 & -0.114 & 0.5447 & -1.00 & 1.00 \\
\hline Change in cultivable land & 289 & -0.467 & 1.6770 & -5.47 & 6.42 \\
\hline Change in value of livestock & 289 & 0.339 & 3.5184 & -10.23 & 10.23 \\
\hline Change in value of jewelry & 289 & -0.183 & 3.8732 & -9.40 & 11.16 \\
\hline Change in value of nonland assets & 289 & 0.198 & 1.1319 & -3.59 & 4.79 \\
\hline Change in value of consumer durables & 289 & 0.191 & 1.1722 & -3.56 & 4.61 \\
\hline Change in value of agricultural durables & 289 & 0.314 & 3.6591 & -10.17 & 10.32 \\
\hline Change in value of nonagricultural durables & 289 & 0.447 & 3.5292 & -9.50 & 10.31 \\
\hline \multicolumn{6}{|c|}{$\underline{\text { Individual-level outcomes }}$} \\
\hline Grade progression & 685 & 2.619 & 1.9465 & 0.00 & 7.00 \\
\hline Change in height for age & 276 & 0.036 & 1.1237 & -3.85 & 3.41 \\
\hline Change in BMI z-score & 273 & -0.055 & 1.0610 & -3.87 & 2.91 \\
\hline
\end{tabular}

Source: Author's calculations.

Note: $\mathrm{BMI}=$ body mass index.

\footnotetext{
${ }^{11}$ One hundred decimals equals one acre of land. This variable was also logged with one decimal added to all values to avoid having to take the log of zero values for landless households.

${ }^{12}$ Stunting is defined as height for age less than -2 standard deviations below the World Health Organization (WHO) reference standard, and low body mass index is defined as a score less than 18.5 (thin) using the WHO reference standards for 5to 19-year-olds (De Onis et al. 2007).
} 
In contrast, the three individual outcome variables (grade progression, change in height for age, and change in BMI) are measured in absolute units and do not have a percentage interpretation. Grade progression shows the number of grades a child of primary-school age advanced between 2000 and 2006. The mean number of grades progressed was 2.62, but a large number of children (128) did not advance any school grades, whereas a handful ( 5 children) advanced seven grades. ${ }^{13}$ Changes in height for age and BMI are for children younger than 13 years old in 2000 and are expressed as absolute changes in their zscores. ${ }^{14}$ There are two reasons for the considerably smaller number of observations for these variables. First, children needed to be older than 5 years old in 2000 for their BMIs to be assessed. Second, children had to be present in the household at the time of the interview to be measured, whereas their schooling level could be ascertained by talking to another household member. The z-scores for height for age for these children show a slight increase (of 3.6 percent) whereas those for BMI show a small decrease (5.5 percent); again, these differences are not statistically different from zero at conventional levels.

Finally, it should be noted that although these trends in outcome values are suggestive, they cannot be used to conclude anything about the efficacy of educational transfers in Bangladesh, because of the presence of numerous other confounding factors (in particular, generalized economic growth) as well as systematic differences between beneficiary and nonbeneficiary groups. It is for this reason that the matching methods described in the next section are employed.

\footnotetext{
${ }^{13}$ Note that grade progression relates to children who were of primary school age (6 to 12 years) at some point during 2000 and 2006. Thus, mean grade progression is reduced by children who were less than 6 years old in 2000 and entered primary school in later years.

${ }^{14}$ The new WHO reference groups for children 5 to 18 years old are used for calculating these z-scores.
} 


\section{METHODOLOGY}

The core of the evaluation problem is how to assess the counterfactual problem: What would have happened to beneficiaries in the absence of the intervention or treatment (Baker 2000; Khandker, Koolwal, and Samad 2010; Todd 2006). Random assignment of the treatment to a pool of equally eligible individuals or households followed by a comparison of outcomes for the treatment and control groups before and after treatment is probably the simplest way to solve the evaluation problem (Duflo and Kremer 2003). This approach is at the heart of the randomized control trial approach to evaluating development interventions popularized by the Jamil Latif Poverty Action Lab at the Massachusetts Institute of Technology. However, randomized control trials are not appropriate for evaluating all interventions either because of sectorwide effects or because it is politically or institutionally infeasible to randomize the allocation of the intervention. In a countrywide program such as PES, random allocation of beneficiaries to treatment and control groups is clearly infeasible.

The approach used in this paper therefore rests on a quasi-experimental or observation approach, which constructs comparable treatment and comparison groups using covariate and propensity score matching. Through comparisons with experimental estimators, Heckman, Ichimura, and Todd (1997) and Heckman et al. (1998) show that propensity score matching (PSM) provides reliable, low-bias differencein-difference estimates of program impact provided that (1) the same data source is used for participants and nonparticipants, (2) participants and nonparticipants have access to the same markets, and (3) the data include meaningful explanatory variables capable of identifying program participation. Our Bangladesh panel data meet all these requirements. In addition, they contain an unusually wide range of outcome variables and information about the household-level variables (household demographic, main occupation, land ownership, and sharecropping) that determines the eligibility of households to receive PES to be assessed directly.

The matching procedure involves several steps. For household- and individual-level outcomes, the propensity scores for participation in PES (or FFE) are estimated using a probit model that includes both determinants of program eligibility and factors that affect the outcome. Heckman, Ichimura, and Todd (1998) emphasize that the quality of the match rests on ensuring that matches are formed only where the densities of the propensity scores overlap between treatment and comparison observations, which is known as the "common support." Common support can be improved by dropping treatment observations whose estimated propensity scores are greater than the maximum or less than the minimum of the comparison group's propensity scores. Similarly, comparison group observations with a propensity score below the minimum or above the maximum of the treatment observations are usually dropped. ${ }^{15}$

Having calculated the propensity scores, treatment and comparison observations were matched using two methods: local linear matching and nearest-neighbor matching. Nearest-neighbor matching pairs observations from the treatment and comparison groups with similar propensity scores. As nearestneighbor matching allows an observation to be used as a match more than once, it typically provides larger sample sizes for the comparison group than local linear matching. Nearest-neighbor matching was implemented using Stata's NNMATCH command (Abadie et al. 2004), specifying five matches in the comparison group for each treatment observation. In contrast to nearest-neighbor matching, local linear matching performs well in samples with low densities of the propensity score in the interior of the propensity score distribution. Although local linear regression matching typically requires more observations than nearest-neighbor matching, it serves as a useful robustness check. Local linear matching was implemented using a tricube kernel using Stata's PSMATCH2 command (Leuven and Sianesi 2003).

Two complications with applying matching methods for the evaluation of the medium-term impact of PES using the Bangladesh panel data should be noted. First, although the eligibility criteria for

\footnotetext{
${ }^{15}$ The distribution of propensity scores for the comparison group often lies to the left of the distribution for the treatment group for targeted social programs. As a result, the highest propensity scores tend to come from treatment observations, whereas the lowest are dominated by comparison observations. This pattern indicates effective targeting.
} 
receiving FFE and PES are similar, and the PES eligibility criteria remained consistent between 2003 and 2006, the requirement that households contain at least one primary-school-age child means that the sample of treatment and comparison households varies over time. Simply because children age, many of the households that would have been eligible to receive PES in 2000 (had it existed then) would not be eligible to receive PES in 2006 - even if all other household characteristics remained constant between the two years. ${ }^{16}$ To circumvent this problem, this paper therefore defines the treatment group as households that were eligible to receive the PES in both 2000 and 2006 and the comparison group as households that were ineligible to receive the PES (despite having at least one primary-school-age child) in both years. This means that households that moved from being eligible to being ineligible to receive transfers (or vice versa) are excluded from the sample, which further reduces the sample of households that can be used for the matching by almost a half to 258 households. Second, although our first panel wave in 2000 predates the implementation of the PES in July 2002, in two-thirds of our sample union councils, some households were FFE beneficiaries. This means that matched difference-in-difference estimates in these unions identify the average treatment effect on the treated (ATT) of the PES relative to FFE. To isolate the impact of PES alone, a sample consisting of households from non-FFE unions plus those households from FFE unions that never were eligible to receive the educational transfers is also constructed. Although this further reduces the sample size to 228 households, this second sample does allow the calculation of ATTs that are uncontaminated by the effects of the earlier FFE program.

In closing, it should be noted that several other approaches have been considered for evaluating the impact of education transfers. Initially, the research team had thought that regression discontinuity design, which compares the outcomes of individuals or households just above a threshold with those just below a threshold, might be a promising approach. However, regression discontinuity design works best when sample sizes are relatively large and when there is a sharp discontinuity between those who are eligible to receive the treatment and those who are not. The sample lacks a clear breaking point when I assess each of the eligibility criteria against households' PES status and is also relatively small. Regression discontinuity design therefore does not seem a promising approach in this context.

An alternative approach is that of panel regressions using continuous outcome variables, with the treatment's being instrumented to control for its endogeneity. This approach has the advantage that it does not require households whose eligibility status changes during the panel to be excluded from the sample. In theory, it can also distinguish between the effects of FFE and PES in the three panel years. However, the efficiency of the instrumental variables approach relies on selection of instrumental variables that are highly correlated with the receipt of FFE or PES but uncorrelated with the outcome variables. Unfortunately, the nature of the five PES eligibility criteria makes it unlikely that this orthogonality condition will be met.

\footnotetext{
${ }^{16}$ For example, a near-landless household whose youngest child attended grade 1 of primary school in the 2000/01 academic year would no longer be eligible to receive PES in 2006/07 if the child had completed primary school on track in 2004/05.
} 


\section{DESCRIPTIVE ANALYSIS OF THE IMPACT OF EDUCATION TRANSFERS}

As noted above, the PES can be received by households with primary-school-age children only. Officially, the age range for primary-school enrollment in Bangladesh is 6 to 10 years old, implying that primary-school children should enroll in grade 1 at the age of 6 and complete grade 5 when they are between 10 and 11 years old. However, Figure 2 shows that 15.5 percent and 35.3 percent of the children receiving PES in 2003 and 2006, respectively, were older than 11 years old. With some 15- and 16-yearold children receiving the PES, it is clear that the age criterion for receiving PES is not at all strictly enforced. It seems that the late age of pupils' enrollment in primary school in rural areas has therefore been accommodated rather than countered by the PES.

Figure 2. Primary Education Stipend (PES) recipients, by age

2003

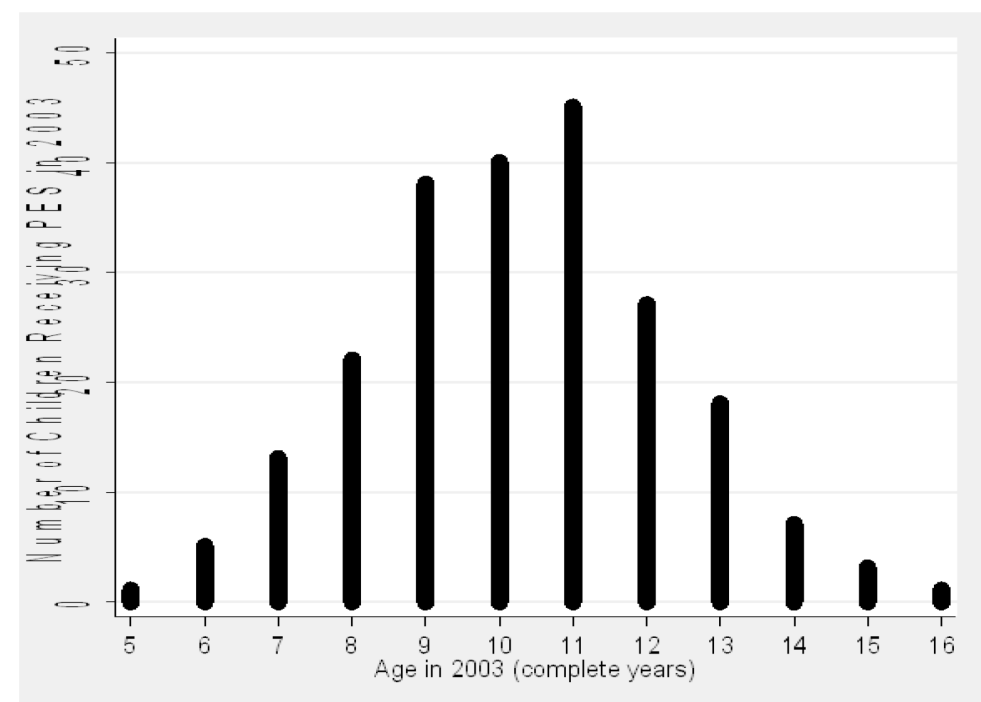

2006

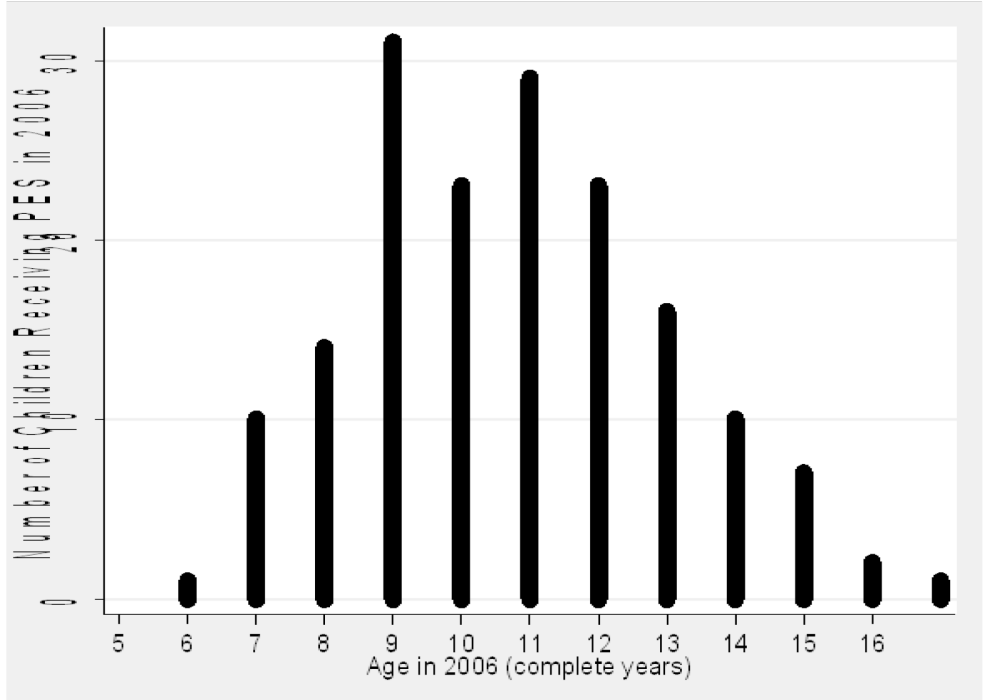

Source: Author's creation. 
How well does the PES reach the 40 percent of the poorest households that it is intended to target? Figure 3 shows the proportion of all households receiving educational transfers in 2000, 2003, and 2006, by expenditure quintile. Two trends are apparent from this figure. First, the shapes of the benefit incidence curves for 2000 and 2006 are generally downward sloping, indicating that the FFE and PES are slightly progressive. However, in 2003, the year after the PES was introduced, the middle quintile received a higher share of the PES than the poorest two quintiles. Furthermore, the shapes of the curves for all three years are relatively flat and decline sharply only in the richest quintile. Under effective targeting, one would expect these benefit incidence curves to decline more sharply in the top three quintiles. Second, at all deciles, a smaller share of households receives the educational transfers in successive survey rounds. In part, this reflects ageing of the households within the panel (all but 2 percent of whom had primary-school-age children in 2000) but may also reflect reductions in the overall numbers of PES recipients over time.

\section{Figure 3. Proportion of households receiving educational transfers}

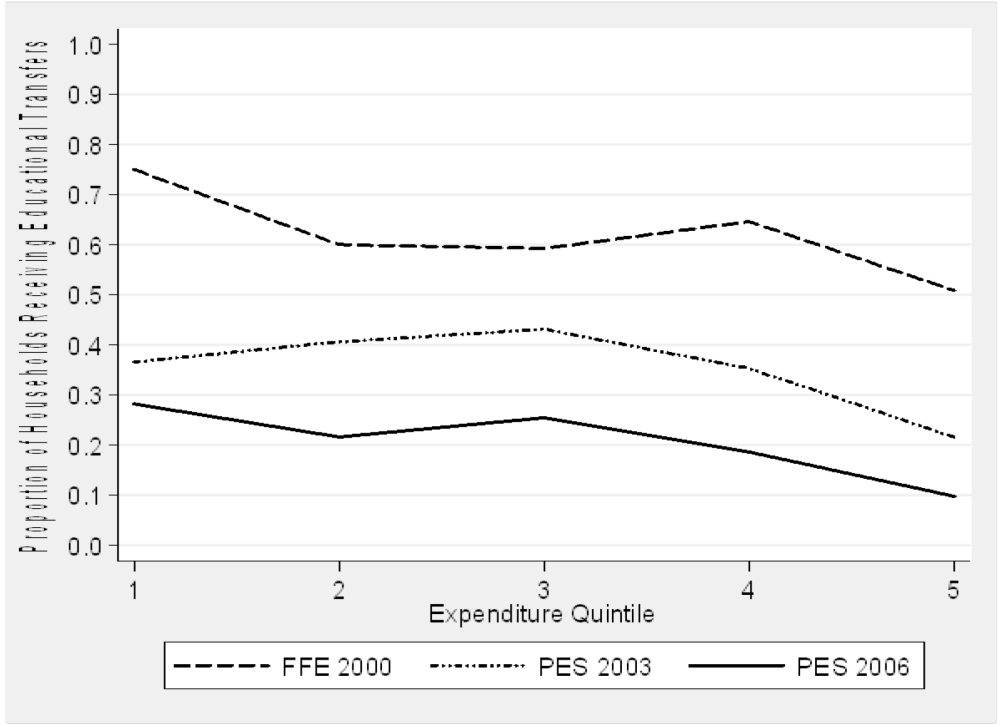

Source :Author's creation.

Note: FFE = Food for Education; PES = Primary Education Stipend.

It is also interesting to note that in 2003, although mothers were registered to receive PES in 98 percent of households, mothers actually collected the stipend in 92 percent of households. (Unfortunately, similar data are not available for the 2006 survey wave.)

It is conventional to distinguish between two errors of targeting: errors of inclusion and errors of exclusion (also known as leakages and undercoverage). ${ }^{17}$ Using the five criteria for the stipend outlined in section 2, Table 2 and Table 3 examine the targeting of the PES program. These tables show that errors of inclusion are greater than errors of exclusion. This is consistent with the budgetary restrictions that restrict the number of children that school management committees can select to receive PES. Nevertheless, 17.1 percent of households receiving PES in 2003 were not entitled to receive it, and this percentage had risen to 27.4 percent by 2006. (Note also that the decline in errors of exclusion between 2003 and 2006 indicates the ageing of children in the panel rather than improved targeting.).

\footnotetext{
${ }^{17}$ Following Cornia and Stewart (1995), they are also known as E and $\mathrm{F}$ errors, where the $E$ stands for excessive coverage and $F$, the failure to reach the target population.
} 
Table 2. Targeting of the Primary Education Stipend (PES) program, 2003

\begin{tabular}{cccc}
\hline & \multicolumn{3}{c}{ Eligible for PES, 2003 } \\
\cline { 2 - 4 } PES Status, 2003 & Yes & No & Total \\
\hline Beneficiary & 82.9 & 17.1 & 100.0 \\
Nonbeneficiary & 55.4 & 44.6 & 100.0 \\
Total & 65.2 & 34.8 & 100.0 \\
\hline
\end{tabular}

Source: Author's calculations.

Table 3. Targeting of the Primary Education Stipend (PES) program, 2006

\begin{tabular}{cccc}
\hline & \multicolumn{3}{c}{ Eligible for PES, 2006 } \\
\cline { 2 - 4 } PES Status, 2006 & Yes & No & Total \\
\hline Beneficiary & 72.6 & 27.4 & 100.0 \\
Nonbeneficiary & 31.6 & 68.4 & 100.0 \\
Total & 40.1 & 59.9 & 100.0 \\
\hline
\end{tabular}

Source: Author's calculations.

The above findings are consistent with other studies that confirm the weak targeting and lightness of the conditionality of PES. For example, Hossain (2009) argues that schools often "adjust" the eligibility criteria and school attendance records to ensure that "deserving" students receive PES. ${ }^{18}$ The weak targeting of the PES is further exacerbated by the fact that its decentralised targeting requires that school management committees pick the same percentage of pupils to receive the stipend, whatever the overall level of poverty within a locality (Al-Samarrai, 2009).

We now turn to examining how selected outcome variables differ by PES beneficiary status (Table 4). As in Table 1, the sample in this table is restricted to households with at least one primaryschool-age child in 2006. For all but four of the household-level outcomes, the changes in the outcomes variables are higher for PES beneficiaries than for non-PES beneficiaries. However, as the $p$ (probability) values for the unpaired t-test reported in the last column show, only two of the differences in householdlevel outcomes are statistically different from zero using conventional level of significance. These two outcomes are the change in stunting among children younger than 13 years old and the percentage of children enrolled in primary school. However, for the change in stunting, the change among PES beneficiary households is greater than for nonbeneficiary households - most probably because PES beneficiaries tend to be slightly poorer than nonbeneficiaries. For the percentage of children enrolled in primary school, what makes the difference between PES beneficiaries and nonbeneficiaries significant is not the size of the increase among PES beneficiaries but that the nonbeneficiary group had around 20 percent fewer children enrolled in primary school in 2006 than in 2000. If enrollments are disaggregated by grade as in Figure 4, there is actually little visual difference in enrollments by PES status. Although a substantial increase in the proportion of children enrolled in grade 1 between 2000 and 2006 together with subsequent progression through the grades can be seen in this figure, there is little difference between the plots for PES beneficiaries and nonbeneficiaries. It is therefore difficult to attribute the increase in enrollment to PES. In short, these crude difference-in-difference estimates show PES has limited impact on outcomes at the household level.

\footnotetext{
${ }^{18}$ An evaluation of the PES program in 2005 found that attendance figures were exaggerated for a third of eligible stipend holders. In addition, 7 percent of beneficiaries received payments despite failing the last annual examination (Al-Samarrai 2009).
} 
Table 4. Change in outcome variables by Primary Education Stipend (PES) status

\begin{tabular}{|c|c|c|c|c|c|c|c|}
\hline \multirow[t]{2}{*}{ Outcome Variable } & \multicolumn{3}{|c|}{ PES Beneficiaries } & \multicolumn{3}{|c|}{ Nonbeneficiaries } & \multirow[b]{2}{*}{$p$ Value } \\
\hline & $n$ & Mean & Standard Deviation & $n$ & Mean & Standard Deviation & \\
\hline \multicolumn{8}{|c|}{ Household-level Outcomes } \\
\hline Change in per capita expenditures & 98 & 0.404 & 0.433 & 193 & 0.420 & 0.477 & .777 \\
\hline Change in per capita food expenditures & 98 & 0.356 & 0.467 & 193 & 0.407 & 0.464 & .383 \\
\hline Change in per capita nonfood expenditures & 98 & 0.680 & 0.728 & 191 & 0.615 & 0.832 & .497 \\
\hline Change in adult equivalent expenditures & 98 & 0.949 & 0.494 & 193 & 0.897 & 0.512 & .401 \\
\hline Change in adult equivalent food expenditures & 98 & 0.901 & 0.537 & 193 & 0.884 & 0.515 & .791 \\
\hline Change in adult equivalent nonfood expenditures & 98 & 1.225 & 0.731 & 191 & 1.093 & 0.837 & .171 \\
\hline Change in per capita calorie consumption & 98 & 0.036 & 0.386 & 192 & 0.033 & 0.354 & .945 \\
\hline Change in per capita protein consumption & 98 & -0.312 & 0.443 & 192 & -0.277 & 0.461 & .536 \\
\hline Change in adult equivalent calorie consumption & 98 & 0.581 & 0.459 & 192 & 0.511 & 0.434 & .215 \\
\hline Change in adult equivalent protein consumption & 98 & 0.233 & 0.514 & 192 & 0.201 & 0.514 & .617 \\
\hline Change in stunting among children younger than 13 & 98 & 0.222 & 0.447 & 193 & 0.065 & 0.426 & .005 \\
\hline Change in low BMI among children younger than 13 & 98 & 0.076 & 0.417 & 193 & 0.076 & 0.375 & .998 \\
\hline Change in children enrolled in primary school & 98 & 0.075 & 0.499 & 193 & -0.209 & 0.543 & .000 \\
\hline Change on cultivable land & 98 & -0.316 & 1.448 & 191 & -0.545 & 1.782 & .241 \\
\hline Change in value of livestock & 98 & 0.603 & 3.115 & 191 & 0.204 & 3.709 & .336 \\
\hline Change in value of jewelry & 98 & -0.080 & 4.208 & 191 & -0.236 & 3.700 & .755 \\
\hline Change in value of nonland assets & 98 & 0.257 & 1.031 & 191 & 0.169 & 1.182 & .513 \\
\hline Change in value of consumer durables & 98 & 0.319 & 1.115 & 191 & 0.126 & 1.198 & .175 \\
\hline Change in value of agricultural durables & 98 & 0.454 & 3.542 & 191 & 0.243 & 3.725 & .638 \\
\hline Change in value of nonagricultural durables & 98 & 0.197 & 3.364 & 191 & 0.574 & 3.613 & .380 \\
\hline \multicolumn{8}{|c|}{ Individual-level outcomes } \\
\hline Grade progression & 270 & 2.419 & 1.912 & 415 & 2.749 & 1.960 & .029 \\
\hline Change in height for age & 99 & 0.125 & 0.867 & 177 & -0.013 & 1.244 & .282 \\
\hline Change in BMI z-score & 101 & -0.055 & 1.062 & 172 & -0.056 & 1.064 & .995 \\
\hline
\end{tabular}

Source: Author's calculations.

Note: $\mathrm{BMI}=$ Body Mass Index. 
Figure 4. Proportion of children enrolled in school, by Primary Education Stipend (PES) beneficiary status

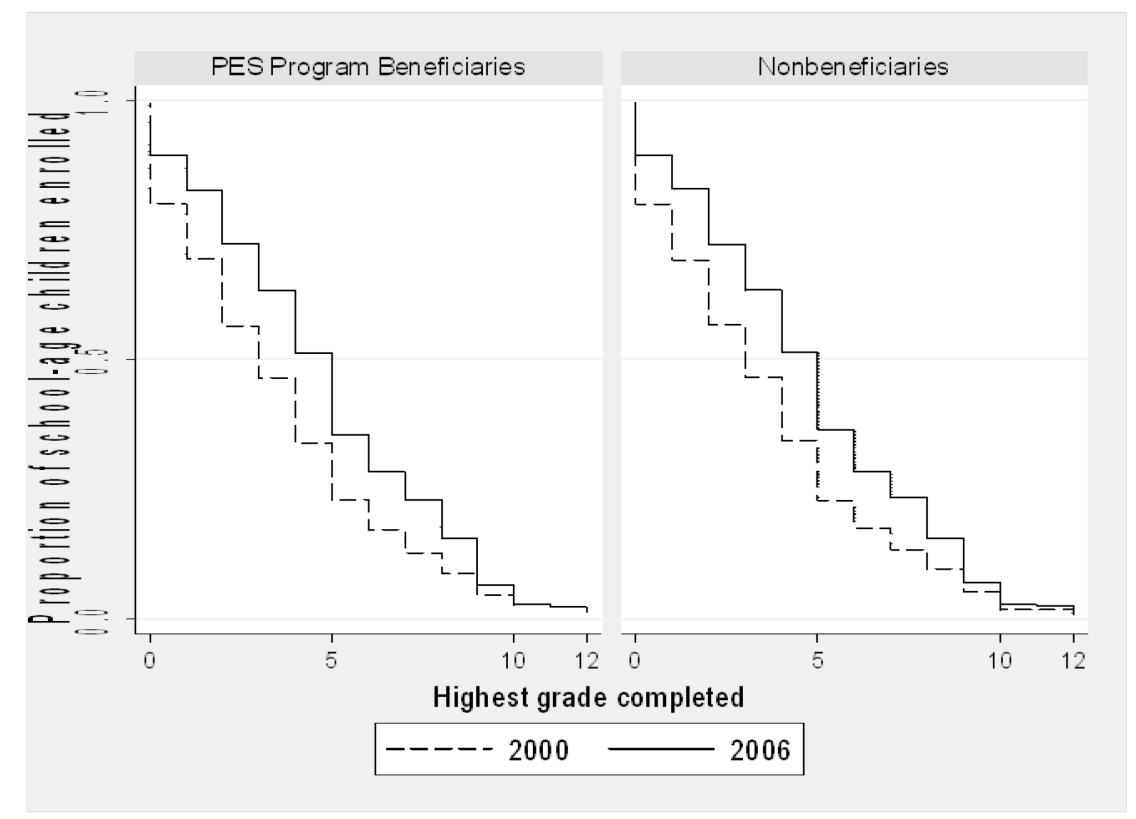

Source: Constructed by author.

Moving on to individual-level outcomes, the only one of the three outcomes considered that is statistically significant from zero is that for grade progression (the number of grades a child of primaryschool age in 2006 has advanced). However, like the percentage of children enrolled in primary school, the change in this variable between 2000 and 2006 is larger for the nonbeneficiary than the beneficiary group.

For individual-level anthropometric outcomes, height for age z-scores improve among PES beneficiaries but worsen among nonbeneficiaries, whereas BMI z-scores decline for both groups. However, both of these changes are small and are not significantly different from zero at conventional levels.

A final point that should be noted is that the number of households receiving PES in 2006 is less than half of the number of beneficiary households in 2003. This phenomenon, which is related to panel ageing, makes it vital to ensure that households with similar characteristics are compared when constructing difference-in-difference estimates of the impact of the PES. Otherwise many of the apparent changes in the outcome variables could simply be due to differences in households' characteristics (including PES status' changing between panel waves). Such comparisons are facilitated by the matching methods used in the next section. 


\section{EMPIRICAL RESULTS}

This section contains the paper's main results on the impact of PES on a range of individual- and household-level outcomes using the methodology described in section 4 . The outcomes selected go beyond the conventional measures used to assess the performance of educational interventions and are broadly comparable with those in the companion paper by Kumar and Quisumbing (forthcoming) on the long-term impact of agricultural technology. So too is the matching methodology, which uses household characteristics at baseline (2000) plus shock variables to construct treatment and comparison groups. ATT is then used to show the impact of PES eligibility on different outcome variables. ATT is estimated using a standard difference-in-difference methodology in which the difference in the outcome variable between the treatment and comparison groups in 2000 (difference 1) is deducted from the same difference in 2006 (difference 2).

Figure 5 shows the estimated densities of the propensity scores for the treatment and comparison groups based on matching, using the following baseline characteristics: age of the household head, education of the household head, household size, and the proportion of men and women aged 20 to 34 and 35 to 54 years old in the household (Appendix Table 1). Three shock variables are also included, showing the number of floods the community experienced between 2000 and 2006 together with whether dowries were paid or any members of the household experienced serious illness during the same period. Note that although payment of dowries (which includes other wedding expenditures) is not strictly a shock (since they can be anticipated in advance), studies using the same data attest to its negative impact on households' livelihood trajectories (Davis and Baulch 2009). Selected upazila dummies are also included. This specification of matching covariates meets the balancing condition but decreases the sample from 258 to either 206 or 208 households depending on whether the outcome variable includes nonfood expenditures (which are missing for two households in 2000).

Figure 5. Estimated propensity score at the household leve

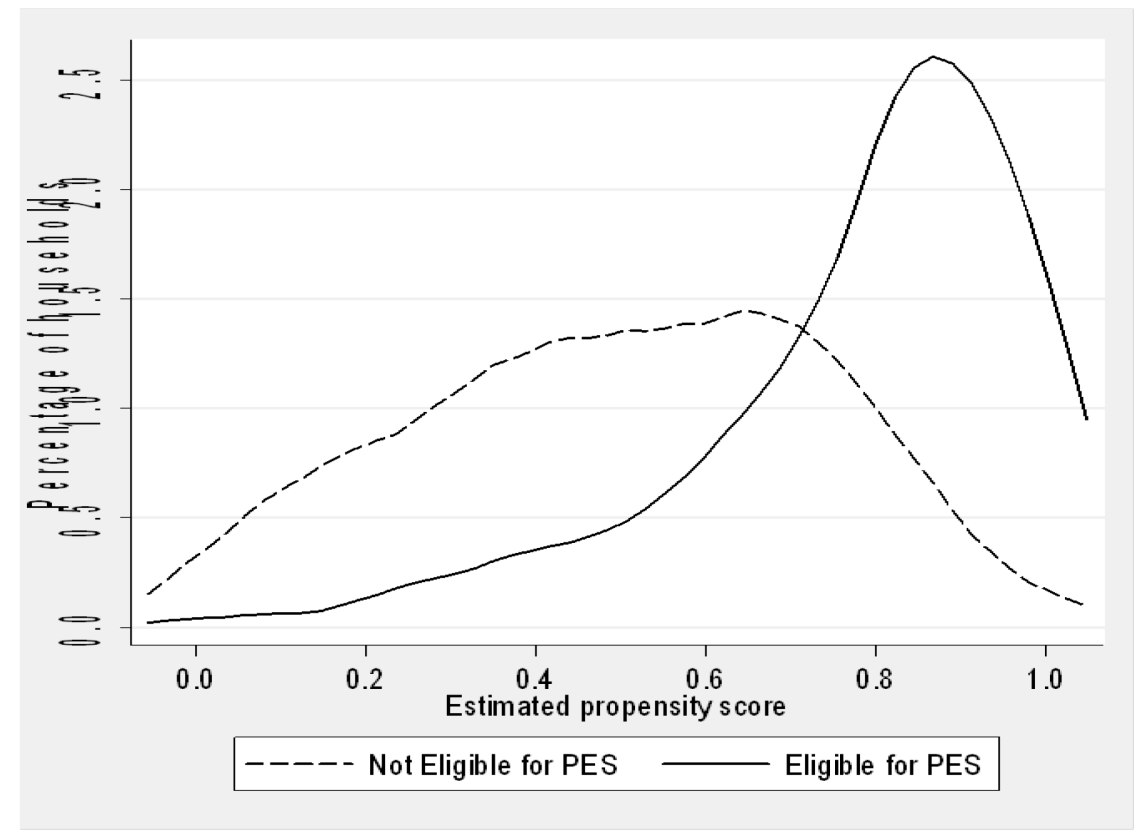

Source: Author's calculations.

Note: PES = Primary Education Stipend. 
Table 5 presents estimated ATTs based on this common sample for a range of outcome variables at the household level using nearest-neighbor matching. For ease of interpretation most of the outcome variables are expressed either in natural logarithms (expenditures and asset values) or as percentages. Although the signs of the impacts of PES are mostly as expected (meaning positive on expenditures, calorie and protein consumption, and assets) most of them are not statistically different from zero at conventional levels. The three exceptions are the percentage of stunted children in the household, the change in the value of consumer durables, and the change in cultivable land. The PES program shows positive and statistically significant impacts on the first two of these variables but a negative effect on land. The effect of PES on stunting, although apparently strong, is not robust and disappears when the alternative matching method of locally linear regressions is used. This is also the case for the change in cultivable land, which one would expect to decline to some extent over the period due to the practice of partible land inheritance in Bangladesh. The effect on consumer durables is robust to matching methods and suggests that although PES may have had only marginal effects on current consumption levels, it does protect households from income variability due to shocks, thereby allowing assets to be gradually built up over time. ${ }^{20}$ However, by far the biggest surprise from Table 5 is that PES does not have a discernible impact on primary-school enrollments at the household level.

Table 5. Household-level impacts of the Primary Education Stipend, 2000-2006

\begin{tabular}{lrrr}
\hline & \multicolumn{3}{c}{ Nearest-neighbor Matching } \\
\cline { 2 - 4 } \multicolumn{1}{c}{ Outcome Variable } & $\boldsymbol{n}$ & ATT & $\boldsymbol{p}$ value \\
\hline Change in per capita expenditures & 167 & 0.1058 & .240 \\
Change in per capita food expenditures & 167 & 0.1341 & .150 \\
Change in per capita nonfood expenditures & 167 & 0.0510 & .691 \\
Change in adult equivalent expenditures & 167 & 0.1611 & .096 \\
Change in adult equivalent food expenditures & 167 & 0.1894 & .054 \\
Change in adult equivalent nonfood expenditures & 167 & 0.1064 & .431 \\
Change in per capita calorie consumption & 166 & 0.0502 & .442 \\
Change in per capita protein consumption & 166 & 0.1311 & .138 \\
Change in adult equivalent calorie consumption & 166 & 0.1100 & .170 \\
Change in adult equivalent protein consumption & 166 & 0.1909 & .058 \\
Change in percentage of stunted children & 167 & 0.1897 & .018 \\
Change in percentage of low-body mass index children & 167 & 0.0050 & .939 \\
Change in primary school enrollment & 167 & -0.0748 & .427 \\
Change on cultivable land & 167 & -0.4325 & .027 \\
Change in value of livestock & 167 & -0.0237 & .968 \\
Change in value of jewelry & 167 & 0.2610 & .695 \\
Change in value of nonland assets & 167 & 0.1626 & .361 \\
Change in value of consumer durables & 167 & 0.3492 & .045 \\
Change in value of agricultural durables & 167 & 0.8044 & .223 \\
Change in value of nonagricultural durables & 167 & -0.6303 & .299 \\
\hline
\end{tabular}

Source: Author's calculations.

Note: ATT $=$ average treatment effect on the treated.

As noted in the Methodology section estimating ATTs using the full sample of households identifies the impact of the PES program relative to the FFE program in unions in which FFE previously operated. So in Table 6, the sample is restricted to non-FFE unions in 2000 plus households living in FFE unions that were never eligible to receive PES. Unfortunately, since only a third of the unions in the 2000

\footnotetext{
${ }^{20}$ This finding is consistent with the findings of a recent International Food Policy Research Institute study of the impact of the Productive Safety Net Program in Ethiopia (Gilligan, Hoddinott, and Taffesse 2008).
} 
sample were non-FFE unions and many of noneligible households living in FFE unions did not have primary-school-age children, the sample is reduced by more than half (to just 70 households). This sample size is too small for locally linear regression matching to identify ATT. However, nearestneighbor matching (with replacement) is able to identify ATT in this case. As can be seen from Table 6, most ATTs are not statistically significant from zero. However, the change in the percentage of children (younger than 12 years old) with low BMI is statistically significant at the 5 percent level and negative, suggesting that by 2006 PES had led to a one-fifth decline in low-BMI children. In addition, ATT for the change of the value of consumer durables is positive and statistically significant at the 10 percent level. However, again the majority of ATTs (including the one for primary-school enrollments) are not statistically different from zero.

Table 6. Household-level impacts of the Primary Education Stipend in restricted sample, 2000-2006

\begin{tabular}{lccc}
\hline \multirow{2}{*}{ Outcome Variable } & \multicolumn{2}{c}{ Nearest-neighbor Matching } \\
\cline { 2 - 4 } & $\boldsymbol{n}$ & $\mathbf{A T T}$ & $\boldsymbol{p}$ value \\
\hline Change in per capita expenditures & 70 & 0.1828 & 0.134 \\
Change in per capita food expenditures & 70 & 0.2106 & 0.103 \\
Change in per capita nonfood expenditures & 70 & 0.1824 & 0.359 \\
Change in adult equivalent expenditures & 70 & 0.1253 & 0.344 \\
Change in adult equivalent food expenditures & 70 & 0.1532 & 0.266 \\
Change in adult equivalent nonfood expenditures & 70 & 0.1250 & 0.548 \\
Change in per capita calorie consumption & 70 & 0.1293 & 0.177 \\
Change in per capita protein consumption & 70 & 0.2056 & 0.106 \\
Change in adult equivalent calorie consumption & 70 & 0.0718 & 0.525 \\
Change in adult equivalent protein consumption & 70 & 0.1482 & 0.287 \\
Change in percentage of stunted children & 70 & 0.2372 & 0.064 \\
Change in percentage of low-body mass index & & & \\
children & 70 & -0.1954 & 0.046 \\
Change in primary school enrollment & 70 & 0.1696 & 0.241 \\
Change on cultivable land & 70 & -0.3468 & 0.300 \\
Change in value of livestock & 70 & -0.0848 & 0.921 \\
Change in value of jewelry & 70 & 0.0000 & 1.000 \\
Change in value of nonland assets & 70 & 0.1471 & 0.540 \\
Change in value of consumer durables & 70 & 0.4689 & 0.073 \\
Change in value of agricultural durables & 70 & 0.4193 & 0.648 \\
Change in value of nonagricultural durables & 70 & 0.2059 & 0.819 \\
\hline Source: Aus & & & \\
\hline
\end{tabular}

Source: Author's calculations.

Note: ATT $=$ average treatment effect on the treated.

We now move to considering the impact of PES's individual-level outcomes. The common support samples at the individual level are larger than at the household level because some households have more than one primary-school-age child, and nearly all had children younger than 12 years old in $2000 .^{21}$ This allows more overlap (common support) between those eligible and not eligible for PES, which in turn allows more precision in estimation of ATT (Figure 6 and Appendix Table 2). It is also possible for these individual outcome variables to be disaggregated by gender.

\footnotetext{
${ }^{21}$ Note that anthropometric indicators were collected from boys younger than 13, plus females younger than 19 and all mothers in the 2000 survey. Anthropometry on all available household members was collected in the 2006 survey.
} 
Figure 6. Estimated propensity scores at the individual level

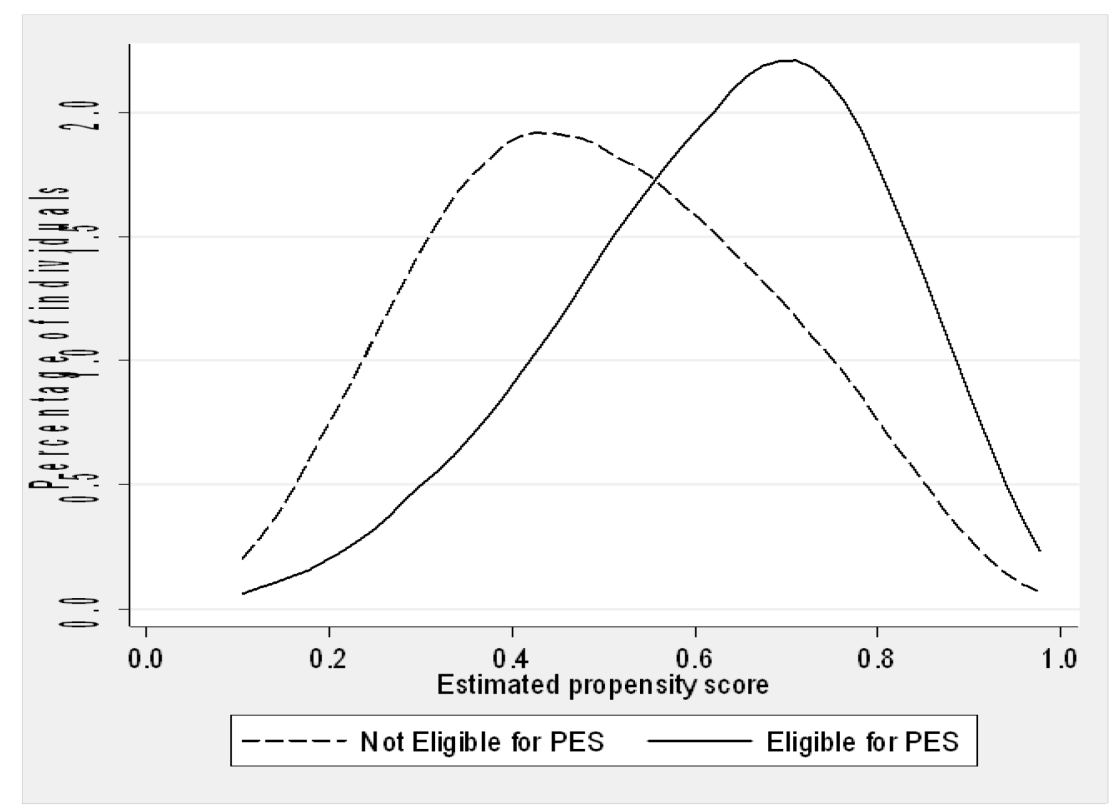

Source: Author's calculations.

Note: PES = Primary Education Stipend.

Table 7 shows the individual-level impacts of the PES between 2000 and 2006 for all children of primary-school age in 2006, and for boys and girls considered separately. For the anthropometric indicators, the effects of PES are all positive but not statistically different from zero. However, for grade progression, ATT is negative and statistically different from zero at the 10 percent level when boys and girls are considered together. This is a relatively weak result given the size of the sample, but the sign and size of the treatment effect is consistent with the half a grade difference in grade progression between PES and non-PES beneficiaries noted earlier. The negative sign is also consistent with the decline in primary enrollment rates observed in the unmatched sample.

Table 7. Individual-level impacts of the Primary Education Stipend, 2000-2006

\begin{tabular}{lccc}
\hline & \multicolumn{3}{c}{ Nearest-neighbor matching } \\
\cline { 2 - 4 } Outcome Variable & $\boldsymbol{n}$ & SATT & $\boldsymbol{p}$ value \\
\hline & Boys and Girls & & \\
Grade progression & 668 & -0.2531 & .090 \\
Change in height for age & 276 & 0.1510 & .341 \\
Change in BMI z-score & 274 & 0.1803 & .161 \\
& Boys Only & & \\
Grade progression & 341 & -0.240 & .282 \\
Change in height for age & 122 & -0.093 & .510 \\
Change in BMI z-score & 121 & 0.268 & .136 \\
& Girls Only & & \\
Grade progression & 327 & -0.231 & .242 \\
Change in height for age & 154 & 0.336 & .183 \\
Change in BMI z-score & 153 & 0.145 & .412 \\
\hline
\end{tabular}

Source: Author's calculations.

Note: SATT = Sample Average Treatment Effect; BMI = Body Mass Index. 
As was the case with the household-level outcomes, the number of observations is too small to allow ATT to be estimated when the sample is restricted to non-FFE unions and nonbeneficiaries in FFE unions with locally linear regression matching. However, ATT can be estimated using nearest-neighbor matching for this sample and produces the results shown in Table 8. The results, which remove the confounding impact of FFE for some households, show PES continuing to have a negative impact on grade progression for boys and girls together, with the decline in grade progression among boys being twice that for girls. The likely explanation for this difference is that unlike girls, boys from poor households are ineligible to receive stipends at the secondary-school level. Once, they reach the age of 11 or 12, employment opportunities for boys in rural areas are also much more abundant than they are for girls. A significant increase in height for age and BMI for boys and girls considered together is also detected in Table 8 . However, the change in BMI is statistically significant only for boys, whereas the change in height for age is statistically significant only for girls. The latter finding is particularly surprising as stunting tends to develop before school enrollment age and is hard, if not impossible, to reverse (Golden 1994).

Table 8. Individual-level impacts of the Primary Education Stipend, 2000-2006

\begin{tabular}{lccc}
\hline & \multicolumn{3}{c}{ Nearest-neighbor Matching } \\
\cline { 2 - 4 } Outcome Variable & $\boldsymbol{n}$ & \multicolumn{1}{c}{ SATT } & $\boldsymbol{p}$ value \\
\hline & Boys and Girls & & \\
Grade progression & 280 & -0.4374 & .037 \\
Change in height for age & 111 & 0.5755 & .009 \\
Change in BMI z-score & 111 & 0.5074 & .008 \\
& Boys Only & & \\
Grade progression & 155 & -0.5466 & .067 \\
Change in height for age & 57 & 0.1252 & .592 \\
Change in BMI z-score & 57 & 0.8194 & .008 \\
& Girls Only & & \\
Grade progression & 125 & -0.2154 & .453 \\
Change in height for age & 54 & 1.3104 & .000 \\
Change in BMI z-score & 54 & 0.3174 & .195 \\
\hline
\end{tabular}

Source: Author's calculations.

Note: $\mathrm{SATT}=$ Sample Average Treatment Effect; BMI = Body Mass Index. 


\section{CONCLUSIONS AND POLICY IMPLICATIONS}

This paper has analyzed the medium term impacts of Bangladesh's Primary Education Stipend program. Using propensity score matching methods the PES program is shown to have negligible impacts on a range of outcome variables at both the household and individual level, once the factors which make treatment and comparison group households different are controlled for. Between 2000 and 2006, the PES program is shows few signs of improving primary school enrolments, households' expenditures, or calorie, or protein consumption at the household level. This is consistent with the declining value of the PES (which has remained fixed in nominal terms since 2003) and with Ahmed's (2005) finding on the short-term impact of the PES on food consumption within the household. Looking at a wider range of asset variables reveals wider impacts of the PES program on stunting, ownership of consumer durables and land over the medium term. While these results are not particularly robust, they suggest that the PES may have provided beneficiary households' with some protection from income variability due to shocks, which may in turn allow them to gradually build-up assets over the medium term.

At the individual level, covariate and propensity score matching methods show that the PES has a statistically significant impact on grade progression but that it is paradoxically lower among PES beneficiaries than non-PES beneficiaries. The negative impact on grade progression is strongest among boys from poor households who, unlike girls, are ineligible to receive stipends at the secondary level. There are also some signs of impact on height for age and the body mass index among children of primary-school age, with boys being more likely to experience improvements in their BMIs and girls being more likely to improve their height for age z-scores.

Overall, however, the medium-term impacts of the PES are remarkably small for a program of its size. The PES's well-known problems of poor targeting (Ahmed 2005; World Bank 2008), in particular its lack of coverage combined with its lack of geographical targeting, and the declining value of the cash transfer involved seem to be the most plausible reasons for this lack of impact. For some households, the PES even may have come to be regarded as another form of regular assistance. Since the PES program was renewed for another five-year period in July 2008, it would be timely to review the program's targeting mechanisms and, in particular, whether it would be more efficient to target larger cash transfers to smaller numbers of the poorest households. ${ }^{22}$ If this can be done, the PES program still has great potential to interrupt the intergenerational transfer of poverty for millions of Bangladeshi children.

\footnotetext{
${ }^{22}$ Another policy option would be to replace cash transfers with food transfers. Although a return to FFE has certain attractive features (including its countercyclical and self-targeting nature), the high and variable costs of food transfers plus the substantial leakages associated with their distribution make it an unattractive option to most policymakers.
} 


\section{APPENDIX: SUPPLEMENTARY FIGURE AND TABLES}

Figure A.1. Locations of the education transfer survey sites

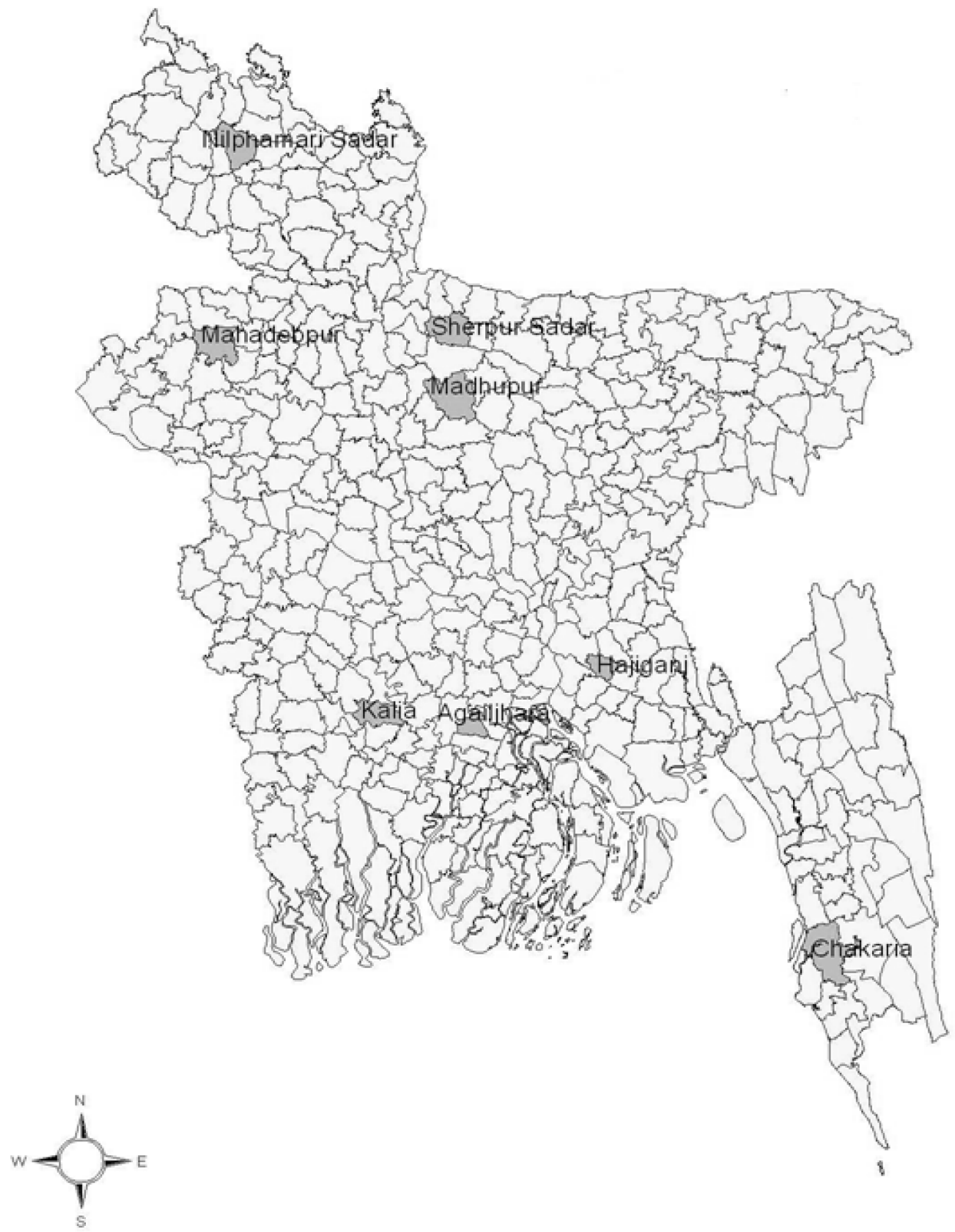

Source: Data Analysis and Technical Assistance Ltd. 


\section{REFERENCES}

Abadie, A., J. Drukker, L. Herr, and G. Imbens. 2004. Implementing matching estimators for average treatment effects in Stata. Stata Journal 4 (3): 290-311.

Ahmed, A. 2005. Comparing food and cash incentives for school in Bangladesh. International Food Policy Research Institute, Washington, D.C., and United Nations University, Tokyo. Mimeo.

Ahmed, A., and Y. Sharma. 1996. Demand elasticities in rural Bangladesh: An application of the AIDS model. Bangladesh Development Studies 23 (1): 1-25.

Ahmed, A. U., and C. del Ninno. 2002. The Food for Education Program in Bangladesh: An evaluation of its impact on educational attainment and food security. FCND Discussion Paper 138. Washington, D.C.: International Food Policy Research Institute.

Ahmed, A. U., and M. Khondakar. 2009. Selected anti-poverty programs in Bangladesh: Institutions, institutional change and policy processes. International Food Policy Research Institute, Washington, D.C. Mimeo.

Al-Samarrai, S. 2007. Financing basic education in Bangladesh. Paper prepared for the Centre for Research on Educational Access and Equity, Institute of Education and Development, BRAC University, Dhaka, Bangladesh.

. 2009. The impact of governance on education inequality: Evidence from Bangladesh. Public Policy and Administration 29:167-179.

Baker, J. 2000. Evaluating the impact of development projects on poverty: A handbook for practitioners. Directions in Development Series. Washington, D.C.: World Bank.

Cornia, A., and F. Stewart. 1995. Two errors of targeting. In Public spending and the poor, ed. D. Van de Walle and K. Nead. Baltimore: Johns Hopkins University Press.

CPRC (Chronic Poverty Research Centre). 2004. Chronic poverty report 2004-05. Manchester, UK: Chronic Poverty Research Centre.

Davis, P. 2007. Discussions among the poor: exploring poverty dynamics with focus groups in Bangladesh. CPRC Working Paper 84. Manchester, UK: Chronic Poverty Research Centre.

Davis, P. Exploring the long-term impact of development interventions within life-history narratives in rural Bangladesh. IFPRI Discussion Paper. International Food Policy Research Institute, Washington, D.C. Forthcoming. Mimeo.

Davis, P., and B. Baulch. 2009. Parallel realities: Using mixed methods to explore poverty dynamics in rural Bangladesh. CPRC Working Paper 142. Manchester, UK: Chronic Poverty Research Centre.

De Onis, M., A. Onyango, E. Borghi, A. Siyam, C. Nishida, and J. Siekmann. 2007. Development of a WHO reference for school-aged children and adolescents. Bulletin of the World Health Organization 85:660-667.

Duflo, E., and M. Kremer. 2003. Use of randomization in the evaluation of development effectiveness. Operations and Evaluation Department, World Bank, Washington, D.C. Mimeo.

Fiszbein, A., and N. Schady. 2009. Conditional cash transfers: Reducing current and future poverty. Policy research report. Washington, D.C.: World Bank.

FPMU (Food Policy Monitoring Unit). various dates. Bangladesh food situation report. Food Policy Monitoring Unit. Dhaka, Bangladesh: Ministry of Food, Dhaka.

Gilligan, D., J. Hoddinott, and A. Taffesse. 2008. The impact of Ethiopia's Productive Safety Net Programme and its linkages. IFPRI Discussion Paper 839. Washington, D.C.: International Food Policy Research Institute.

Golden, M. 1994. Is complete catch-up possible for stunted malnourished children? European Journal of Clinical Nutrition 28:S58-S70.

Heckman, J., H. Ichimura, J. Smith, and P. Todd. 1998. Characterizing selection bias using experimental data. Econometrica 66:1017-1098. 
Heckman, J., H. Ichimura, and P. Todd. 1997. Matching as an econometric evaluation estimator. Review of Economic Studies 65:261-294.

Hossain, N. 2009. School exclusion as social exclusion: The practices and effects of a conditional cash transfer program for the poor in Bangladesh. CPRC Working Paper 148. Manchester, UK: Chronic Poverty Research Centre.

Khandker, S., G. Koolwal, and H. Samad. 2010. Handbook on impact evaluation: Quantitative methods and practices. Washington, D.C.: World Bank.

Kumar, N., and A. Quisumbing. forthcoming. The long-term impact of improved vegetable and fish technologies in Bangladesh: Does early adoption matter? IFPRI Discussion Paper. Washington, D.C.: International Food Policy Research Institute. Forthcoming.

Leuven, E., and B. Sianesi. 2003. PSMATCH2: Stata module to perform full Mahalanobis and propensity score matching, common support graphing, and covariate imbalance testing.

$<$ http://ideas.repec.org/c/boc/bocode/s432001.html $>$. Version 1.2.3.

Ministry of Primary and Mass Education. n.d. Stipend program. <http://www.mopme.gov.bd/Ministry_frm.htm>. Accessed July 25, 2009.

Parker, S., L. Rubalcava, and G. Teruel. 2006. Evaluation conditional schooling and health programs. Handbook of Development Economics, Vol. 4. Amsterdam: North Holland.

Quisumbing, A. 2007. Poverty transitions, shocks and consumption in rural Bangladesh: Preliminary results from a longitudinal household survey. CPRC Working Paper 105. Manchester, UK: Chronic Poverty Research Centre.

Tietjen, K. 2003. The Bangladesh Primary Education Stipend Project: A descriptive analysis. Paper prepared for the Partnership for Sustainable Strategies for Girls Education, Geneva, Switzerland.

Todd, P. 2006. Evaluating social programs with endogenous program placement and selection of the treated. In Handbook of agricultural economics, vol. 4, ed. R. Evenson and T. P. Schultz. Amsterdam: North Holland.

World Bank. 2008. Education for all in Bangladesh: Where does Bangladesh stand in achieving the EFA goal by 2015? Bangladesh Development Series 24. Washington, D.C.: World Bank. 


\section{RECENT IFPRI DISCUSSION PAPERS}

\section{For earlier discussion papers, please go to www.ifpri.org/pubs/pubs.htm\#dp. All discussion papers can be downloaded free of charge.}

975. A review of empirical evidence on gender differences in nonland agricultural inputs, technology, and services in developing countries. Amber Peterman, Julia Behrman, and Agnes Quisumbing, 2010.

974. An experiment on the impact of weather shocks and insurance on risky investment. Ruth Vargas Hill and Angelino Viceisza, 2010.

973. Engendering agricultural research. Ruth Meinzen-Dick, Agnes Quisumbing, Julia Behrman, Patricia Biermayr-Jenzano, Vicki Wilde, Marco Noordeloos, Catherine Ragasa, Nienke Beintema, 2010.

972. Sarpanch Raj: Is the president all powerful? The case of village councils in India. Nethra Palaniswamy, 2010.

971. Asset versus consumption poverty and poverty dynamics in the presence of multiple equilibria in rural Ethiopia. Lenis Saweda O. Liverpool and Alex Winter-Nelson, 2010.

970. Poverty status and the impact of social networks on smallholder technology adoption in rural Ethiopia. Lenis Saweda O. Liverpool and Alex Winter-Nelson, 2010.

969. Wage subsidies to combat unemployment and poverty: Assessing South Africa's options. Justine Burns, Lawrence Edwards, and Karl Pauw, 2010.

968. Patterns and trends of child and maternal nutrition inequalities in Nigeria. Babatunde Omilola, 2010.

967. Foreign inflows and growth challenges for African countries: An intertemporal general equilibrium assessment. Xinshen Diao and Clemens Breisinger, 2010.

966. Biofuels and economic development in Tanzania. Channing Arndt, Karl Pauw, and James Thurlow, 2010.

965. Weathering the storm: Agricultural development, investment, and poverty in Africa following the recent food price crisis. Babatunde Omilola and Melissa Lambert, 2010.

964. Who has influence in multistakeholder governance systems? Using the net-map method to analyze social networking in watershed management in Northern Ghana. Eva Schiffer, Frank Hartwich, and Mario Monge, 2010.

963. How to overcome the governance challenges of implementing NREGA: Insights from Bihar using process-influence mapping. Katharina Raabe, Regina Birner, Madhushree Sekher, K.G. Gayathridevi, Amrita Shilpi, and Eva Schiffer, 2010.

962. Droughts and floods in Malawi: Assessing the economywide effects. Karl Pauw, James Thurlow, and Dirk van Seventer, 2010 .

961. Climate change implications for water resources in the Limpopo River Basin. Tingju Zhu and Claudia Ringler, 2010.

960. Hydro-economic modeling of climate change impacts in Ethiopia. Gene Jiing-Yun You and Claudia Ringler, 2010.

959. Promises and realities of community-based agricultural extension. Gershon Feder, Jock R. Anderson, Regina Birner, and Klaus Deininger, 2010.

958. Rethinking the global food crisis: The role of trade shocks. Derek D. Headey, 2010.

957. Female participation in African agricultural research and higher education - New insights: Synthesis of the ASTI-award benchmarking survey on gender-disaggregated capacity indicators. Nienke M. Beintema and Federica Di Marcantonio, 2010.

956. Short- and long-term effects of the 1998 Bangladesh Flood on rural wages. Valerie Mueller and Agnes Quisumbing, 2010 .

955. Impacts of the triple global crisis on growth and poverty in Yemen. Clemens Breisinger, Marie-Helen Collion, Xinshen Diao, and Pierre Rondot, 2010.

954. Agricultural growth and investment options for poverty reduction in Nigeria. Xinshen Diao, Manson Nwafor, Vida Alpuerto, Kamiljon Akramov, and Sheu Salau, 2010.

953. Micro-level practices to adapt to climate change for African small-scale farmers: A review of selected literature. Till Below, Astrid Artner, Rosemarie Siebert, and Stefan Sieber, 2010. 


\section{INTERNATIONAL FOOD POLICY RESEARCH INSTITUTE}

www.ifpri.org

IFPRI HEADQUARTERS

$2033 \mathrm{~K}$ Street, NW

Washington, DC 20006-1002 USA

Tel.: +1-202-862-5600

Fax: +1-202-467-4439

Email: ifpri@cgiar.org

IFPRI ADDIS ABABA

P. O. Box 5689

Addis Ababa, Ethiopia

Tel.: +251116463215

Fax: +251116462927

Email: ifpri-addisababa@cgiar.org

IFPRI NEW DELHI

CG Block, NASC Complex, PUSA New Delhi 110-012 India

Tel.: 9111 2584-6565

Fax: 9111 2584-8008 / 2584-6572

Email: ifpri-newdelhi@cgiar.org 